\title{
EEN PAAR OPMERKINGEN
}

\author{
DOOR
}

\section{K. KESLER}

In het Januari-nummer van dit tijdschrift komt een zeer lezenswaardig artikel voor onder den titel ,Nederland en Suriname". Met het grootste gedeelte van wat de, op dit gebied zeer deskundige, schrijver met betrekking tot de verhouding van beide onderdeelen van Grooter Nederland vermeldt, kan men het onvoorwaardelijk eens zijn. Er zijn echter enkele punten, zij het een paar van ondergeschikt belang, waar het moeilijk valt, de beschouwingen van den schrijver voetstoots te aanvaarden. Het eerste is dat, waar deze de kwestie der watervoorziening aanroert. Het is ongetwijfeld waar, dat de wijze, waarop deze geregeld is, tot protesten aanleiding gegeven heeft. En het moge ook waar zijn, dat er h.t.l. beoordeelaars geweest zijn, die het er niet geheel mede eens waren, hoofdzakelijk kwamen die protesten toch uit Suriname. Wat eenigszins onbegrijpelijk is, als men in aanmerking neemt, hoe ongelukkig en gebrekkig die watervoorziening daar geregeld, of eigenlijk niet geregeld, was. Goede huizen hebben daar plaatijzeren tanks, waarin zich het op de daken neervallende hemelwater langs goten en aanvoerbuizen verzamelt. Het neervallende hemelwater - en nog heel wat meer, wat blijkt, als men ze in een huis, dat men gaat betrekken, eens grondig inspecteert en ze daarna laat schoonmaken. Menschen van onzen tijd, die gewoon zijn aan de haast ideale toestanden op het gebied van watervoorziening, die hier algemeen zijn, althans in grootere plaatsen, zouden moeite hebben, te gelooven, wat er bij zoo'n schoonmaak wel te voorschijn komt. Het minste is wel een laag modder, van onbekende samenstelling natuurlijk - een laag van allicht een voet dik.

Maar die vergaarplaatsen van regenwater en allerlei daarin rondzwevende ongerechtigheden wil men behouden en men protesteert er tegen, dat in de plaats van die middeleeuwsche zaken een moderne waterleiding zal komen. Waarom? Omdat dat niet 
voor niets kan geschieden; omdat men voor een emmer zuiver water een kleinigheid zal dienen te betalen, terwijl men thans regenwater met allerlei erin, wat er niet in behoort, voor niets kan krijgen.

En nog om een andere reden,'n.l. omdat de gebenedijde regenbakken waardeloos zullen worden. Daartegen wordt vooral door huiseigenaars geprotesteerd. Liever ongebreidelde voortwoekering van allerlei volksziekten, die met onzuiver of althans suspect water in verband staan, dan een verlies van enkele guldens, dat ten slotte toch wel op de huurders verhaald zal worden! Het kost eenige moeite, aan te nemen, dat de schrijver werkelijk meent, dat ,ernstige twijfel aan de opportuniteit en de wijsheid van den genomen maatregel gerechtvaardigd is". En het heeft geen zin, nog eens uitvoerig het voor en tegen van die waterleiding tegen elkaar te gaan afwegen. De toekomst zal wel bewijzen, zooals dit in Amsterdam en overal hier ter lande bewezen is, dat degenen, die de volksgezondheid gewichtiger achten dan een tijdelijk verlies van enkele honderden guldens aan toch meer dan driekwart versleten materiaal, het bij het rechte eind hadden.

Hier heeft zijn historische zin den schrijver in den steek gelaten. En nog op een andere plaats, waar hij schrijft over de zuiverheid onzer taal in Suriname en over den naam „creolen”, dien de inlanders zich daar met een zekere voorkeur toekennen.

Wat de schrijver omtrent die twee punten in het midden brengt is voor een groot deel ongetwijfeld waar. In Suriname - en hierin vormt het een groote tegenstelling met Curaçao - spreekt men over het algemeen onze taal zuiver. En dat is te danken aan het goed georganiseerde onderwijs; ook daarin kan men zonder voorbehoud met den schrijver medegaan. Dat echter de geboren Hollander „te vaak” gemeend heeft, zich vroolijk te kunnen maken over woorden en uitdrukkingen die in Suriname gangbaar zijn, maar ons vreemd in de ooren klinken, laten wij liefst voor zijn eigen rekening. Zooals wij boven schreven, het schijnt, dat zijn historische zin hem hier in den steek laat.

Over die onwelwillende Hollanders, die zich „,vroolijk maken” over zekere woorden en uitdrukkingen willen wij liefst niet spreken. Ze zullen er wel zijn; er zijn onder alle klassen en onder alle nationaliteiten nu eenmaal zulke lieden te vinden. Maar, dat zij ongelijk hebben, als zij een open oor hebben voor dit verschijnsel, is hun niet kwalijk te nemen. Indien een woord of uitdrukking wij zullen hier geen voorbeelden geven, maar er zijn er inderdaad genoeg - op voor ons zonderlinge wijze gebruikt wordt, dan 
mogen wij dit toch wel als Surinamisme bestempelen, al is het misschien waar, dat het in vroegeren tijd, in de XVIIIe eeuw door geletterden in Nederland werd gezegd en geschreven, of thans nog in de Vlaamsche letterkunde wordt gebruikt.

De taal is toch een levend organisme, dat voortdurend zich ontwikkelt, oude woorden en vormen verliest of uitstoot, en nieuwe vormt of aanneemt. Dat is overal het geval en wanneer Suriname met „archaismen”, indien men „Surinamismen” liever niet wil, achterblijft bij het Moederland, is het toch niet kwaad, daarop te wijzen, zonder zich er vroolijk over te maken.

Men zou gaan denken, dat de schrijver geheel en al een voorstander is van behoud van het oude, al is dat ook in andere deelen van Groot-Nederland meer speciaal hier, waar de taal gevormd en vervormd wordt, in onbruik geraakt en vergeten.

Dat blijkt niet het geval te zijn, althans niet met betrekking tot wat hij opmerkt omtrent het woord „Creolen”. Niemand, ook schrijver dezes niet, zal ontkennen dat dit woord in Suriname en, naar het schijnt, ook in Fransch West-Indië en in Spaansch-Amerika thans in een andere dan in de oorspronkelijke beteekenis gebruikt wordt. In den gedachtengang van den schrijver zou dus o.i. deze beschouwing passen, dat die beteekenis niet de juiste is. Joséphine de Beauharnais was ongetwijfeld „une créole”. Haar geslacht was uit Frankrijk op Martinique gekomen en de familie Tascher de la Pagérie, waaruit zij afstamde was onvermengd Fransch van oorsprong. Zij was dus een blanke, geboren in de West en dus ,"une créole". Laat men die voorwaarde van blanke afstamming los, dan is er niets tegen, ieder, die in de West geboren is, creool te gaan noemen, naar den door den schrijver gegeven Spaansch-Amerikaanschen regel. Toch geeft deze nog eenige moeilijkheid, want de bijvoeging „pero no indigena de ella" schijnt Indianen uit te sluiten. Wij zouden geneigd zijn te zeggen: Zoek nu maar eens uit, wie wel en wie niet „creool” genoemd moet worden. Intusschen, het schijnt ons toe, dat dit alles met „raswaan" (een ongenaam klinkend woord tusschen haakjes) niet veel te maken heeft en verder, dat deze verdediging van een nieuwe beteekenis, in de West toegekend aan een eeuwenlang bestaand woord, wel eenigszins in strijd is met streven naar behoud van het antiquarische en verdediging daarvan. 